Comment

\title{
Comment on Nover et al. Leaching via Weak Spots in Photovoltaic Modules. Energies 2021, 14, 692
}

\author{
Parikhit Sinha ${ }^{1, *(1)}$ and Andreas Wade ${ }^{2}$ \\ 1 First Solar, 350 West Washington Street, Suite 600, Tempe, AZ 85281, USA \\ 2 First Solar, Amelia-Mary-Earhart-Straße 8, 60549 Frankfurt, Germany; andreas.wade@firstsolar.com \\ * Correspondence: parikhit.sinha@firstsolar.com
}

check for

updates

Citation: Sinha, P.; Wade, A. Comment on Nover et al. Leaching via Weak Spots in Photovoltaic Modules Energies 2021, 14, 692. Energies 2021, 14, 3150.

https://doi.org/10.3390/ en14113150

Received: 16 February 2021

Accepted: 1 April 2021

Published: 28 May 2021

Publisher's Note: MDPI stays neutral with regard to jurisdictional claims in published maps and institutional affiliations.

Copyright: (C) 2021 by the authors. Licensee MDPI, Basel, Switzerland. This article is an open access article distributed under the terms and conditions of the Creative Commons Attribution (CC BY) license (https:// creativecommons.org/licenses/by/ $4.0 /)$.

\section{Introduction}

In their recent publication on "Leaching via Weak Spots in Photovoltaic Modules" [1], Nover et al. have extended their previous long-term leaching study on photovoltaic (PV) modules [2], by increasing test duration and by examining a larger set of elements ( $\mathrm{Al}, \mathrm{Cd}$, $\mathrm{Cu}, \mathrm{Ga}, \mathrm{In}, \mathrm{Mo}, \mathrm{Pb}, \mathrm{Se}, \mathrm{Te}, \mathrm{Zn}$ ) and mechanisms of delamination. Based on their results, the authors argue for prompt replacement of damaged modules and complete recycling of end-of-life modules. Both recommendations are sensible from commercial (maximizing energy yield) and circular economy perspectives. However, some of the study's methods would benefit from clarification.

We have been following the authors' research for several years, beginning with their leaching experiments on milled PV modules (0.2 mm grain size) [3], and later their longterm leaching experiments on PV module pieces $\left(5 \times 5 \mathrm{~cm}^{2}\right)$ [2]. After the latter publication, we commented on various methodological aspects such as the representativeness of $\mathrm{pH} 3$ citric acid solution for rainwater leaching, comparisons with actual long-term rainwater leaching tests, and the need for fate and transport analysis to assess risk [4]. Those comments were discussed in turn by the authors [5].

\section{The Role of Buffering on $\mathrm{pH}$}

An important difference between the authors' initial research on milled PV modules [3] and the later studies on PV module pieces [1,2] is the use of buffered aqueous solution. In the initial research, the $\mathrm{pH} 3$ leaching solution ( $0.1 \%$ acetic acid) was not buffered, and due to the $\mathrm{PV}$ module glass composition, $\mathrm{pH}$ increased during leaching experiments with a difference of $\Delta \mathrm{pH}=\mathrm{pH}_{\mathrm{end}}-\mathrm{pH}_{\text {start }} \approx+3$ [3]. In the later studies, the $\mathrm{pH} 3$ leaching solution consisted of $15.4 \mathrm{~g} / \mathrm{L}$ citric acid, buffered with $2.8 \mathrm{~g} / \mathrm{L}$ disodium hydrogen phosphate. As a result of the buffering, $\mathrm{pH}$ remained almost constant at 3 throughout the study [1,2].

In our own experiments, we also observed $\mathrm{pH}$ to increase over time without buffering. Figure 1 shows pH of crystalline silicon (c-Si) and cadmium telluride (CdTe) PV module pieces in sulfuric and nitric acid aqueous solution, increasing from a starting $\mathrm{pH}$ of 4.2 to $5.5-6.0$ after 92 days. The reason the $\Delta \mathrm{pH}$ is less than the $\approx+3$ observed in [3] is that the PV module pieces were larger $(1 \mathrm{~cm} \times 1 \mathrm{~cm})$ and there was no agitation, compared with a $0.2 \mathrm{~mm}$ grain size and continuous shaking in [3]. For perspective, the median $\mathrm{pH}$ of rainfall in Germany [6] and the United States (U.S.) [7] in 2018 is also shown in Figure 1, and is higher than the $\mathrm{pH}$ of 3 utilized by Nover et al. and the starting $\mathrm{pH}$ of 4.2 in our experiments.

By comparing $\mathrm{pH} 3,7$, and 11 aqueous solutions, Nover et al. have shown that $\mathrm{pH}$ is a key parameter influencing long-term leaching rates. Therefore, this difference in a constant versus increasing $\mathrm{pH}$ plays a key role in their results and interpretation. The rate and magnitude of leaching observed by Nover et al. in the $\mathrm{pH} 3$ aqueous solution would be reduced without buffering. In actual field conditions, buffering would also not be 
present, and a long-term (1-year) leaching study in actual rainwater found that leachate concentrations meet environmental limits [8].



- CdTe PV (water-jet cut, $1 \mathrm{~cm} \times 1 \mathrm{~cm}, 20: 1$ liquid-solid ratio, room temperature, no agitation) in unbuffered aqueous solution (H2SO4/HNO3 60/40 weight \%)

$\Delta \quad$ c-Si PV (water-jet cut, $1 \mathrm{~cm} \times 1 \mathrm{~cm}, 20: 1$ liquid-solid ratio, room temperature, no agitation) in unbuffered aqueous solution (H2SO4/HNO3 60/40 weight \%);

- - Median of annual average pH of rainfall across measurement stations in 2018 (Germany [6], United States [7])

- - - c-Si | CdTe PV (water-jet cut, $5 \mathrm{~cm} \times 5 \mathrm{~cm}$ ) in buffered aqueous solution $(15.4 \mathrm{~g} / \mathrm{L}$ $\mathrm{C} 6 \mathrm{H} 8 \mathrm{O} 7,2.8 \mathrm{~g} / \mathrm{L} \mathrm{Na} 2 \mathrm{HPO} 4)$ [1-2]

Figure 1. The $\mathrm{pH}$ of crystalline silicon (c-Si) and cadmium telluride (CdTe) photovoltaic (PV) module pieces in buffered and unbuffered aqueous solution over time, along with median $\mathrm{pH}$ in rainfall in Germany and the U.S. in 2018. (Note-sulfuric acid: $\mathrm{H}_{2} \mathrm{SO}_{4}$, nitric acid: $\mathrm{HNO}_{3}$, citric acid: $\mathrm{C}_{6} \mathrm{H}_{8} \mathrm{O}_{7}$, disodium hydrogen phosphate: $\mathrm{Na}_{2} \mathrm{HPO}_{4}$ )

\section{Field Representativeness}

More generally, Nover et al. have shown that leaching is a function of several variables such as $\mathrm{pH}, \mathrm{eH}$, time, temperature, and encapsulation. We have practical experience with these variables through the operation of high-value recycling operations (Figure 2). Glass and semiconductors are recovered from end-of-life PV modules with a high (>90\%) yield, by optimizing those variables. Those conditions are artificial and do not occur in nature, and it is likewise difficult to relate the long-term leaching test conditions (e.g., years-long immersion in buffered $\mathrm{pH} 3$ citric acid solution) to field conditions.

To account for field conditions, commercial PV modules are subject to safety and reliability test sequences established by Underwriters Laboratory (UL) in the U.S. and the International Electrotechnical Commission (IEC) internationally. Figure 3 shows types of reliability tests undertaken by solar panel manufacturers, which include heat and humidity stress testing, wind load and hail testing, wet leakage testing, and radiation exposure.

In addition to testing, the PV industry has a multi-decade track record in the field, having deployed over $600 \mathrm{GW}$ of PVs [9]. In the PV industry, safety and commercial expectations are aligned, because a broken PV module does not produce electricity. Steps are taken across the life cycle of the PV module to ensure long-term durability and safety. These steps include encapsulated solid-state module design, with edge sealant along the module perimeter to block water ingress. As described in Figure 3, PV module designs are tested with reliability and safety protocols to qualify them for the market. Once deployed in the field, operations and maintenance (O\&M) practices are used to monitor electricity production, and remove non-functioning PV modules from the field. Performance monitor- 
ing of solar projects is standard in large-scale systems, and also available in smaller scale systems (commercial and state-of-the-art residential systems). These life cycle management steps are reflected in low field breakage rates (0.04\%/year) [10] and environmental safety at operating solar plants with respect to ecological soil screening limits [11].

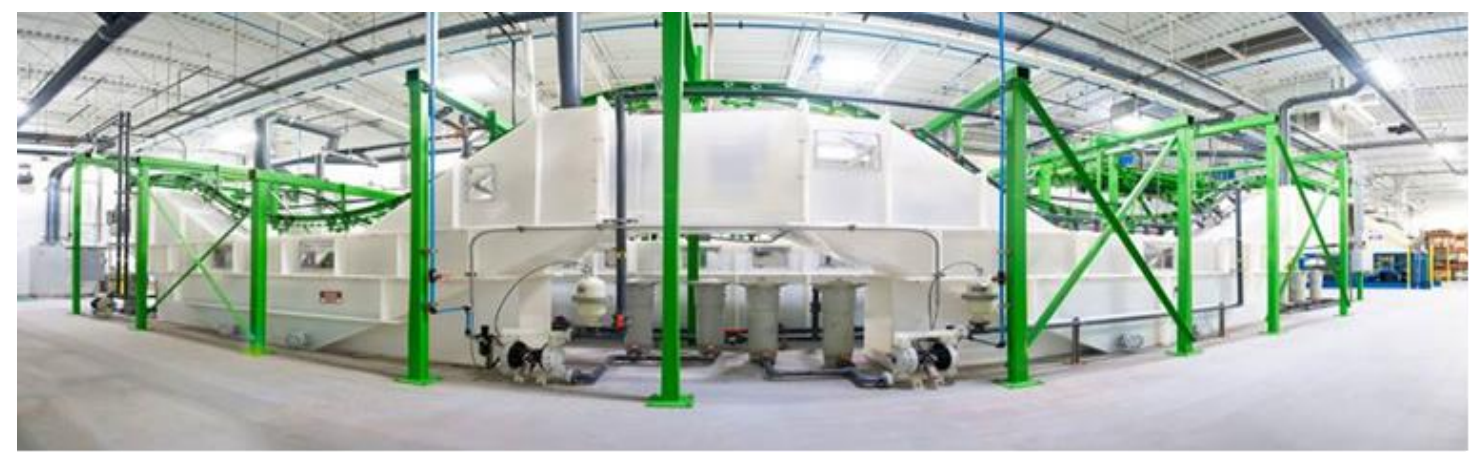

Figure 2. First Solar high-value PV recycling facility recovering glass and semiconductors with $>90 \%$ yield.
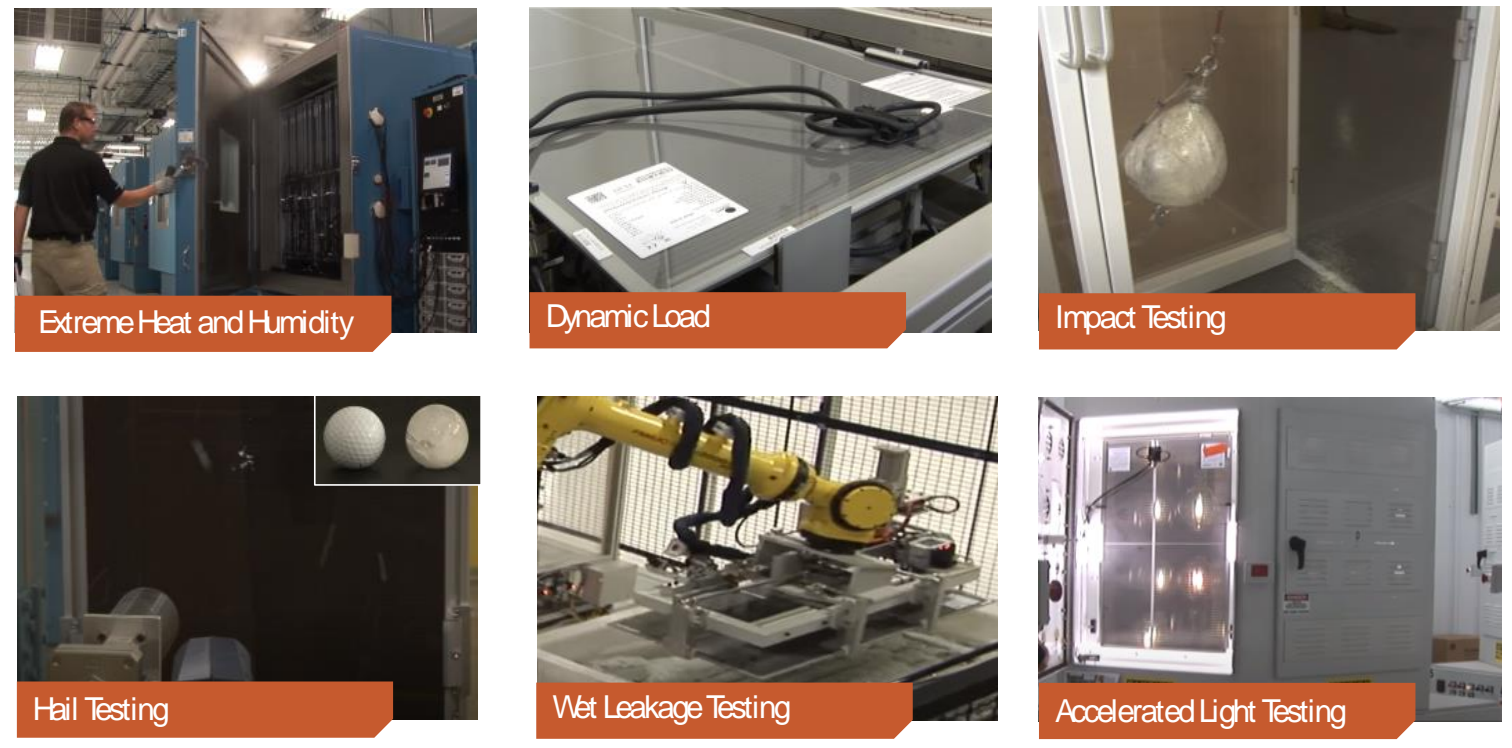

Figure 3. Examples of PV module reliability and safety tests at First Solar reliability laboratory in Perrysburg, Ohio, U.S.

At end-of-life, the most sustainable treatment option is recycling from both environmental and resource efficiency perspectives. In the EU, the Waste Electrical and Electronic Equipment (WEEE) directive has included PV modules in its scope since 2012, and PV module recycling has been implemented commercially [12]. Standards for high-value PV recycling have been developed by the European Committee for Electrotechnical Standardization (CENELEC) (EN 50625-2-4 and TS 50625-3-5 [13]) that include de-pollution specifications for the maximum allowable metal content in output glass. With respect to end-of-life landfill disposal, recent research from Nain and Kumar shows that standard short-term waste characterization tests overestimate leaching risks from PV modules, in comparison to observed long-term (60-day) leaching using actual landfill leachate [14]. Rather than just extending the duration of leaching tests, as done by Nover et al., Nain and Kumar recommend making them more representative of field conditions in order to accurately assess environmental risks.

Environmental risk assessment methods for field breakage and disposal of PV modules have been outlined in IEC TS 62994 [15]. In addition to leaching concentration, the methods account for field parameters such as fate and transport pathways and exposure factors, in order to assess potential ecological and human health risks. 
Author Contributions: Writing—original draft preparation, P.S.; writing—review and editing, A.W. Both authors have read and agreed to the published version of the manuscript.

Funding: This research received no external funding.

Conflicts of Interest: The authors declare no conflict of interest.

\section{References}

1. Nover, J.; Zapf-Gottwick, R.; Feifel, C.; Koch, M.; Werner, J.H. Leaching via weak spots in photovoltaic modules. Energies 2021, 14, 692. [CrossRef]

2. Nover, J.; Zapf-Gottwick, R.; Feifel, C.; Koch, M.; Metzger, J.; Werner, J.H. Long-term leaching of photovoltaic modules. Jpn. J. Appl. Phys. 2017, 56, 08MD02. [CrossRef]

3. Zapf-Gottwick, R.; Koch, M.; Fischer, K.; Schwerdt, F.; Hamann, L.; Kranert, M.; Metzger, J.; Werner, J.H. Leaching hazardous substances out of photovoltaic modules. Int. J. Adv. Appl. Phys. Res. 2015, 2, 7. [CrossRef]

4. Sinha, P.; Wade, A. Comment on "Long-term leaching of photovoltaic modules". Jpn. J. Appl. Phys. 2018, 57, 019101. [CrossRef]

5. Nover, J.; Zapf-Gottwick, R.; Feifel, C.; Koch, M.; Metzger, J.; Werner, J.H. Reply to "Comment on 'Long-term leaching of photovoltaic modules'”. Jpn. J. Appl. Phys. 2018, 57, 019102. [CrossRef]

6. Entwicklung des pH-Wertes im Niederschlag an den Messstationen des UBA-Luftmessnetzes. Available online: https://www. umweltbundesamt.de/sites/default/files/medien/384/bilder/dateien/2_abb_entw-ph-wert_2020-06-29.pdf (accessed on 11 February 2021).

7. National Atmospheric Deposition Program. Available online: http://nadp.slh.wisc.edu/data/ntn/ntnAllsites.aspx (accessed on 11 February 2021).

8. Steinberger, H. Health, safety and environmental risks from the operation of CdTe and CIS thin-film modules. Prog. Photovolt. Res. Appl. 1998, 6, 99-103. [CrossRef]

9. Snapshot of Global PV Markets. Available online: https://iea-pvps.org/wp-content/uploads/2020/04/IEA_PVPS_Snapshot_20 20.pdf (accessed on 11 February 2021).

10. Sinha, P.; Wade, A. Assessment of leaching tests for evaluating potential environmental impacts of PV module field breakage. IEEE J. Photov. 2015, 5, 1710-1714. [CrossRef]

11. Robinson, S.A.; Meindl, G.A. Potential for leaching of heavy metals and metalloids from crystalline silicon photovoltaic systems. J. Nat. Resour. Dev. 2019, 9, 19-24.

12. Life Cycle Assesment of Current Photovoltaic Module Recycling. Available online: https://iea-pvps.org/wp-content/uploads/ 2020/01/Life_Cycle_Assesment_of_Current_Photovoltaic_Module_Recycling_by_Task_12.pdf (accessed on 11 February 2021).

13. Waste Electrical \& Electronic Equipment (WEEE)—Standards on WEEE treatment. Available online: https://ec.europa.eu/ environment/waste/weee/standards_en.htm (accessed on 11 February 2021).

14. Nain, P.; Kumar, A. Understanding metal dissolution from solar photovoltaics in MSW leachate under standard waste characterization conditions for informing end-of-life photovoltaic waste management. Waste Manag. 2021, 123, 97-110. [CrossRef] [PubMed]

15. IEC TS 62994:2019 Photovoltaic (PV) Modules through the life Cycle—Environmental Health and Safety (EH\&S) Risk AssessmentGeneral Principles and Nomenclature. Available online: https:/ / webstore.iec.ch/publication/27874 (accessed on 11 February 2021). 